\title{
Discovering Dèduit: An Examination of the Garden Setting in the Roman de la Rose
}

\author{
Irina Ridzuan*
}

The University of Victoria

irinar@uvic.ca

\begin{abstract}
Roman de la Rose is a French poem which chronicles the journey of a young man within a secluded garden setting (the Garden of Dèduit). The poem was initially written by Guillaume de Lorris in c.1230 and later completed by Jean de Meun in c.1270. However, the authors' differing literary styles have resulted in debates surrounding the poem's meaning. In this study, I address the central interpretative problem by focusing on the illustrated garden setting of Dèduit and its relation to the literary content. Ultimately, I attempt to answer the following questions: How did the medieval audience perceive the garden symbolism? Did the images make a difference in the medieval reader's understanding of the garden? What are the possible ways in which the medieval reader could interpret this garden symbolism?
\end{abstract}

Keywords: Roman de la Rose; French poem; illustrated garden setting; text-image relation; medieval manuscripts; medieval readership; medieval book culture; Guillaume de Lorris; Jean de Meun; Garden of Deduit

\section{INTRODUCTION}

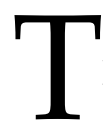
he Garden of Dèduit is a secluded setting in which the narrative of the Roman de la Rose takes place. The French poem is a composite work by two authors. Initially written by Guillaume de Lorris around 1230 (lines 1-4058), the Roman de la Rose chronicles a dream experienced by the main character, called the Lover (L'Amans), and his journey to pluck the Rose. As the Lover faces the trials and tribulations of his conquest, the poem touches upon the nature of virtues, vices, and love. The tone and narrative change with Jean de Meun's section (lines 4059-21864). This was added around 1270, forty years after Lorris's publication. Meun continued the story where Lorris ended it, and in effect revisited the idealistic nature of love as explained by Lorris. By doing so, Meun challenged contemporary courtly culture and the nature of chivalric romances.

\section{ON the Roman De La Rose ANd Its Authors}

The dual authorship of the poem has resulted in various debates about the poem's meaning. Some have proposed that the poem reflects a non-religious, courtly culture of romance while others have maintained the poem is a religious allegory. This divide in scholarship can be attributed to the discrepancy between the two styles of writing in the poem as a whole. This paper adds to existing scholarship by addressing this interpretative problem 11 It starts from the premise that the

\footnotetext{
*I wish to thank Dr. Evanthia Baboula for her invaluable mentorship and encouragement over the past year and Jamie Cassels Undergraduate Research Awards for funding this research.

${ }^{1}$ I will be using the translation of the poem from Old French to English, by F.S. Ellis. Guillaume de Lorris, The Romance of the Rose, trans. By F. S. Ellis (London, UK: J. M. Dent Sons, 1975).
} 
illustrations added in early manuscripts of the Roman de la Rose are important for considering how contemporary readers were meant to understand the poem. In particular, this study examines the illustrations of the Garden of Dèduit and explores the question of what meaning the garden setting conveys to the medieval reader and how the images of the garden contribute to that understanding. Firstly, I will focus on examining the symbolic meaning of the Garden of Dèduit as a literary and visual metaphor. Specifically, I will concentrate on the narrative of the 'discovery of the Garden of Dèduit' as written by Lorris (lines 129-1492) $)^{2}$ Secondly, this paper touches upon the point of medieval readership and book culture with the purpose of uncovering the meaning behind the garden symbolism and its role in reading the poem.

The Roman de la Rose begins with an account of a young man's dream-journey. In this dream, the Lover discovers a secluded garden, which is equated to an earthly paradise called the Garden of Dèduit (Garden of Delight). Within this garden, the protagonist meets personified characters such as Lord Dèduit (the owner of the garden), the God of Love, Reason, and Fair Welcome. These are the characters who aid the Lover's quest to pluck the beautiful Rose with which he falls in love. Continuing the narrative, the rest of Lorris's poem describes the Lover's quest and the obstacles he faces on his journey. This chivalric quest places the poem within the genre of romance literature at the time. As the Lover realizes his love for the Rose and his desire to pluck it, he faces the challenge of defeating the four guardians of the Rose, which are Danger, Fear, Shame, and Evil Tongue. The Lover's quest is guided and aided by allies of his own such as Fair Welcome and Reason. Unfortunately, the initial quest ends in failure as Fair Welcome becomes imprisoned in a high tower, which is guarded by the Rose's guardians. The Lover is removed from his initial joyous state:

\author{
"Darkest fear \\ Invades me, lest it should appear \\ That you forget me quite; what woe \\ Untold would fall on me to know \\ That I had lost [Fair Welcome's] friendship, then \\ Were I unhappiest of men; \\ All pleasure, joy, and comfort sped, \\ And hope itself nigh perished." \\ Ellis, 1975, p. 142, lines 4227-35.
}

This ridding of the Lover's happiness marks the end of Lorris's poem and could be received as a parable: one that concerns itself with the virtuous life and the consequences of immorality.

The chief difference between Lorris's and Meun's poem is the literary style; this reflected different intentions. Meun contributed to the poem by adding his own alternative ending to the poem: the Lover's relentless determination to win the Rose in the name of his master, the God of Love. For the most part, Meun's Roman de la Rose focuses on dialogues between the Lover and Reason - after the former's initial failure - about the nature of love without focusing on virtuous affection, as Lorris did. Due to Meun's digressive and non-linear style, his addition has been thought of as a social commentary and a manifestation of his socio-political opinions (Milan, 1969). Meun's section of the poem includes various historical references. For example, he mentions ancient figures such as Pythagoras, Socrates, and Nero while commenting on a realistic nature of amorous love. This contrasts with Lorris's initial theme of the idyllic nature of love. Despite

\footnotetext{
${ }^{2}$ This study includes a small list of manuscripts (Table 1), which are similar in iconography, and composition of the garden setting. However, it mainly focuses on four exemplary manuscripts—-those indicated with an $\left(^{*}\right)$ in the table.
} 
the difference in narrative trajectory between the two authors and the Lover's initial failure, the poem's entire narrative occurs within an enclosed garden setting (of Dèduit). Therefore, one may ask the question: how did the medieval audience perceive the garden symbolism? Further, did seeing the images of the garden of Dèduit make a difference in how the poem was perceived? In attempt to answer these questions foremostly one must understand what constitutes the Garden of Dèduit.

\section{The GARden of Dèduit: Literary Imagery Versus Illustrations}

How does the poem describe the Garden of Dèduit? Lorris introduces the Garden of Dèduit, from the Lover's perspective in three distinct stages: i) from the exterior, upon the Lover's discovery of the garden (lines 129-522); ii) from a liminal place as the Lover approaches the garden to find an entrance (lines 523-650); and iii) from the interior, after the Lover's entry into the garden (lines 650-1492). The first feature of the garden that the Lover notices is the crenellated wall as seen from the exterior perspective:

\footnotetext{
"Short space my feet had traversed ere

A garden spied I, great and fair,

The which a castle wall hemmed round"

Ellis, 1975, p. 5, lines 137-139.
}

The Lover then describes the ten portraits hanging on the wall. These are the enemies of Lord Dèduit and thus, the ten characters that are forever forbidden from entering the garden. The Lover goes on to name the villainous characters and describe their physical attributes. The ten figures are: Hatred, Felony, Villainy, Covetousness, Avarice, Envy, Sorrow, Old Age, Hypocrisy, and Poverty.

Despite the negative characteristics of these personifications, the Lover is struck with an overwhelming longing to enter this "blest abode" as he discovers it (Ellis, 1975, p. 18). Moving onwards, the protagonist explores the garden from a liminal perspective as he searches for an entrance into the garden. He eventually discovers a "straight and small wicket" (Ellis, 1975, p. 18). As he approaches the entrance, the Lover meets Dame Idleness, who becomes his guide in the garden, as she opens the door and invites the Lover in. After the entry, the author introduces the third view of the garden: the interior. Here, the poem is replete with literary imagery describing every species of birds and trees within the garden. The Lover's experience of the garden setting from within is overwhelmingly paradisiacal. He begins by describing an auditory experience that he likens to a celestial concert. This leads to a dance amongst Lord Dèduit and his company:

\footnotetext{
"For ne'ver ere this, my whole life through,

Did joy so unalloyed bedew

My every sense, and ecstasy

Ran through the very soul of me"

Ellis, 1975, p. 23, lines 689-692.
}

Furthermore, the author mentions various fruit trees (pomegranates, dates, figs) brought from the 'Saracen land' before moving on to describing the animals and the Fountain of Narcissus 3 . The

\footnotetext{
${ }^{3}$ Use of the term 'Saracen' in the poem suggests an insertion of the contemporary perceptions of Muslims: for example,
} 
poem, then, advances into the story of Narcissus and the theme of love and beauty. At this point, the author, Lorris, has introduced the entirety of the garden.

Moving along the three stages in introducing the garden, the poem goes from refrained disclosure to an abundance of literary imagery. The Garden of Dèduit is indeed a frequent visual theme in the early illuminated manuscripts of the Roman de la Rose. However, the accompanying illustrations of the Garden of Dèduit tell a different story. First, the images are not an exact representation of the literary content. In most of the illustrated manuscripts, the three stages of the introduction to the garden are depicted as 'Discovery of the Garden', 'Idleness Opens the Door', and 'Dance in the Garden'. While these three scenes are often present in the illustrated manuscripts, they are composed in varying manners. Some manuscripts depict the 'discovery' and 'entry' scene within one panel of multiple miniatures; as in the cases of Paris, Bibliothèque national de France, Ms. Fr. 23488 (Fig. 8, f.1r) and Oxford, Bodleian Library, Ms. Selden Supra 57 (Fig. 4, f.1r). Here, the introduction process is visually expedited as the first two stages are seen contemporaneously. Both manuscripts depict strikingly similar image compositions: the Lover sleeping in his bed, waking and putting on his shoes, walking outdoors, and eventually discovering the secluded garden. However, in the case of Bodleian Selden Supra 57, the discovery scene is depicted twice: first, within one panel of four miniatures (Fig. 4, f.1r), whereby the Lover dreams of and approaches the garden, and second, in singular and distinct panels. It is clear that the illustrators had some sense of artistic agency in representing the garden.

A consistent difference between the illustration and text is that the elaboration of the former progresses in the opposite direction to the latter; while the text evolves from little information to extensive details, the representation of the garden setting becomes more abstracted as the story advances. In some copies, the three stages are introduced in a linear fashion, with each stage composed in a singular and distinct panel. This occurs in Arras, Bibliothèque municipale d'Arras, Ms. 897 (Fig. 7, f.2r), Châlons-en-Champagne, Bibliothèque municipale d'Châlons-en-Champagne, Ms. 270 (Fig. 4, f.2r) and Bodleian Selden Supra 57 (Fig. 10, f.4v) as mentioned previously. In these singular panels, the discovery scene includes the Lover approaching a crenellated wall while depicting several varied elements. Arras Ms. 897 includes three of the ten portraits of Dèduit's enemies on the wall, and without any indication of trees or any other conventional garden features. The garden is portrayed as a fortress, rather than a fortified garden. In contrast, Bodleian Selden Supra 57 represents the garden with a clean white wall and some tree branches peeking through the crenellations. Nevertheless, these examples demonstrate several similarities across manuscripts: i) the most prominent feature of the garden is the curtain wall, which is to indicate that the garden is contained within the enclosed space; ii) the exterior view of the 'discovery' scene is often represented more concretely than the scenes that occur within the garden ('Dance in the Garden').

The 'discovery' scene is depicted using conventional garden iconography: the castle walls, tree, and birds in some cases. In contrast, the 'dance' scene contains no visual clues to indicate that the narrative is occurring within a garden space. The garden illustrations therefore act as a visual device that is not merely repeating the literary narrative (Lewis, 1992). I suggest that the Garden of Dèduit acts as visual symbolism in its own right in that it is trying to tell a tangential story of its own. But what does the garden symbolism allude to? The abstraction of the Garden of Dèduit is interesting especially when one considers the ending of the Lover's first quest, which is the banishment of the Lover from the garden. I posit that the abstraction process may be

showing Danger with Moorish attributes. Similarly, Largesse, the personification of generosity and friend of Lord Dèduit, is described in textiles imported from the "Mawmet school of Saracens". For detailed analysis, refer to Nadia Altschul, 'Saracens and Race in Roman de la Rose Iconography: The Case of Dangier in MS Douce 195', Digital Philology, A Journal of Medieval Cultures 2 (2013), p. 1-15. 
foreshadowing the loss of the Lover. This relationship of literary and visual imagery makes the transition between the two sections of the poem more dramatic.

\section{Medieval Readership and Reception}

What are the possible ways in which the medieval reader could decipher the garden symbolism? Here, reference to literary and codicological studies the Roman de la Rose manuscripts is relevant. The most substantial debate on the interpretation of the poem is with regard to the religious versus non-religious interpretation. This ongoing discussion comprises of two opposing parties: those who view the poem as an allegory and those who receive it as literal narrative 4 . More recently, scholars have noted the importance of distinguishing whether a literary body is, indeed, an allegory. In the case of the Roman de la Rose, there are several obvious features that suggest an allegorical interpretation. The personified characters is one of the key features; the simple nature of these characters is a major indication of an allegory as they contribute to the didactic role of allegories as exegetical literature and a method of conveying moral Truths (Sturges, 1991). For example, the character of Fair Welcome represents a single aspect of the human personality, which is an inclination towards amorous love. Further, Lorris began his poem by employing a dream-vision device, which reinforces the poem's allegorical nature. This is because dreams often suggest the concept of revelation and inspiration of a hidden truth in medieval literature. With that, one could also note the association between dream visions and prophetic visions, which allows for the audience to infer truth in fiction as the poem continues (Lewis, 1992).

Lorris specifically describes the Garden of Dèduit using literary imageries that invoke the Garden of Eden, an idyllic place that becomes the symbol for existential happiness prior to the Fall. This usage of Edenic imageries, however, is not exclusive to the Roman de la Rose. Many romances from the 14th century onwards mention some form of idyllic pastoral setting, especially the poems pertaining to courtly love, such as the Arthurian chivalric tales of love (Porter, 2003). Additionally, enclosed garden settings in chivalric romances were often presented as a feminine and leisurely space. Considering the educated, upper middle class audience of the Roman de la Rose, these courtly aspects of the enclosed garden would have been familiar to the readers. According to Delumeau (2000), this fascination with romances in the garden setting reflects a collective sense of nostalgia and melancholy for a pure state of being. The enclosed garden can be seen as a shelter and refuge from evils beyond the walls. Worth mentioning is the use of garden settings in miracle stories in the 14th century, such as the annunciation story. Through these religious narratives, nature gained a symbolic meaning. For instance, apples signify the ploys of evil and cherries signify the passion of Christ (Delumeau, 2000). With that, the depiction of the abstracted garden setting as paradisiacal matches Lorris's literary tone and the idealistic views on love and virtues.

On the other hand, the Garden of Dèduit and its Edenic imagery can conjure up a different set of associations. Considering the concept of Eden and the way the poem begins with the notion of slumber, it is possible that the garden alludes to death and the afterlife. As mentioned previously, the visual abstraction that occurs in the introduction of the garden mirrors - and to a certain extent, foreshadows - the removal of the Lover as he develops an amorous desire for the Rose which ends in his banishment. In other words, this plot trajectory reinforces Lorris's caution on

\footnotetext{
${ }^{4}$ Huot (1993), Hult (1986), Luria (1982), and Arden (1987) have separately addressed the confusion surrounding the medieval reception of the Roman de la Rose. All four authors agree that the poem is religious in many ways. Huot and Hult argued that the sensual nature of the garden setting as written in Lorris's poem is significant and the study of the manuscript illustrations allows for further exploration of the non-religious understanding of the poem. On the other hand, Luria and Arden examined the 14th-century debate surrounding the Roman de la Rose's interpretation, known as The Quarrel. Both scholars highlighted the historical arguments of those who insisted that the poem ultimately demonstrated a moral tale.
} 
the unsavoury effects of harbouring unholy desires. In this case, the abstraction of the garden setting reflects Lorris's religious tone more than it does Meun's secular-oriented tone. In fact, this notion of negative consequences is more apparent when considering the genre of texts with which the Roman de la Rose was often paired.

Of the twelve manuscripts mentioned previously, six were paired with other sets of text (Table 1). Interestingly, these manuscripts do not necessarily pair the poem with texts from the same genre. Often, the Roman de la Rose is housed together with testament and/or codicils, a common late medieval tradition, as is the case of Bodleian Selden Supra 57, Bib. Nat. Ms. Fr. 24388, Bib. d'Arras Ms. 897 and Bib. Nat. Ms. Fr. 380. At other times, the poem is paired with multiple texts; Bib. d'Arras Ms. 897 pairs the Roman de la Rose with eleven other distinct texts - four of which include single incipit illustrations. The manuscript includes texts such as the 'Judgement of King Behaigne', 'the History of St. Jean Baptiste, and the 'Purgatory of St. Patrick'. The Roman de la Rose in Bib. Châlons-en-Champagne Ms. 270, on the other hand, is paired with two other texts entitled: i) 'Che Sont les Heures de la Crois' (These Are the Hours of Trust) and ii) prayers written in prose. Similarly, Bib. Nat. Ms. Fr. 380 pairs the poem with a will and another text entitled 'Sept articles de la foi' (Seven Articles of Faith). The pairing of texts is interesting as it shows the poem being associated with a particular theme: a grimmer notion of afterlife than the Edenic setting suggests. A rationale behind this correlation could be the immediacy of the notion of Hell and Judgement in the 14th century. The controversy and debates regarding the afterlife was at its peak during the publication of Dante's Inferno (Turner, 1993). Here, I suggest that the abstracted garden setting in the Roman de la Rose could signify the rising concept of Hell and Judgment in the 14th century, contemporary to Dante's debut. Therefore, the garden setting as a whole inevitably carries a religious connotation as indicated by the poem, its illustrations and the genre of texts with which the poem is paired.

Table 1: Table of manuscripts included in this study. The number of illustrations mentioned only considers those pertaining to the Roman de la Rose in the manuscripts.

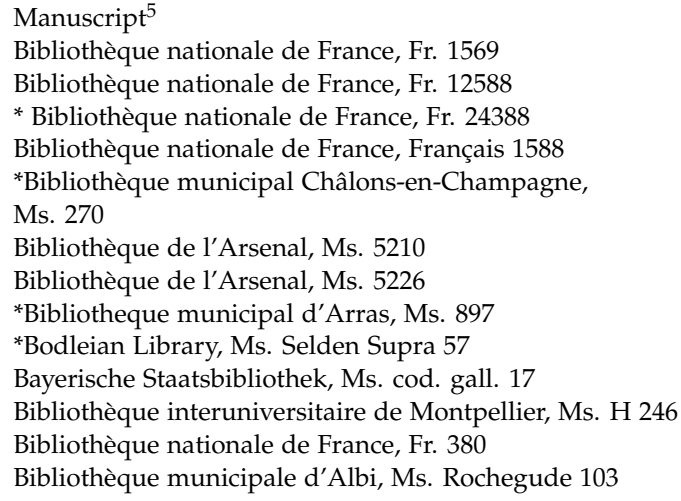

$\begin{array}{llll}\text { Date } & \text { Paired w/ text } & \text { No. of texts } & \text { No. of images } \\ \text { Late13th century } & \text { yes } & 1 & 26 \\ \text { 14th century } & \text { no } & - & 20 \\ \text { 14th century } & \text { yes } & 1 & 44 \\ \text { 14th century } & \text { no } & - & 23 \\ \text { 14th century } & \text { yes } & 2 & 29 \\ \text { 14th century } & \text { no } & - & 31 \\ \text { 14th century } & \text { no } & - & 21 \\ \text { 14th century } & \text { yes } & 11 & 45 \\ \text { 14th century } & \text { yes } & 1 & 53 \\ \text { 14th century } & \text { no } & - & 82 \\ \text { 14th century } & \text { no } & - & 75 \\ \text { 15th century } & \text { yes } & 3 & 47 \\ \text { 15th century } & \text { no } & - & 16\end{array}$

Another theme that is present in these manuscripts and pairing of texts is nostalgia. The Roman de la Rose is sometimes paired with ancient philosophical texts attributed to Aristotle, Socrates, and Solomon. There are two significant corollaries to this: i) the poem fits the genre of exegetical literature or at least is perceived as a textual body worth of contemplation, and ii) the pairing indicates contemporary interest in ancient wisdom. As pointed out by Kelly (1992), the romance genre exists as a derivation of the art of poetry and traditional prose that clerics learned in their training. On the other hand, some scholars have attributed the 12th century revival of

\footnotetext{
${ }^{5}$ Information pertaining to the manuscripts is taken from the Roman de la Rose Digital Library, <romandelarose.org $>$.
} 
Byzantine literary romances as the source of inspiration for Lorris's Roman de la Rose (Warren, 1916). The enclosed garden setting as described in Byzantine tales such as Hysmene and Hysminias is comparable to that in the Roman de la Rose. For this reason, it would be unjustified to claim that the entire Roman de la Rose poem was intended or received purely in terms of religiosity. This picture is further complicated by the fact that all 320 known manuscripts, including the illustrated copies, were produced after Jean de Meun's addition, which centred on more secular-oriented concepts. In other words, the illustrations accompanying Lorris's portion of poem were added after Meun's addition had gained considerable popularity as a completed corpus. This chronological factor further muddles the study of medieval interpretation and reception of the poem. Here, the line between secular and religious art and literature in the medieval world is more complex.

The danger of inferring strictly religious concepts from the Roman de la Rose is that it undermines the complexities of negotiating between secular and religious art in the medieval world (Sturges, 1991). The complexities of the Roman de la Rose ought not to be simplified and reduced to a single theme. Studies of the manuscripts' marginalia are indicative of what has been called "discontinuous modes of reading"(Huot, 1990, p. 402). This meant that the poem was seen as multiple little stories, with their own distinct themes and values that are contained within a larger narrative frame. For instance, one may look at the three stages of garden introduction as an enclosed story that is related to but separate from the story of Narcissus. Additionally, this discontinuous mode of reading parallels Susanne Lewis's suggestion on the illustrations' function as "visual ruptures" which encourages periodic contemplation (Lewis, 1991, p. 215). For example, with the interjection of the illustrations between blocks of texts, the reader is encouraged to contemplate the images before moving on to reading the next stanza. Additionally, the active function of the illustrations implies that they not merely representing the textual information in visual form. The function of the images is to provide information differently from their literary companion. By visually representing these narratives, the illustrators/patrons are able to diminish and emphasize or disregard and embellish certain aspects of the text. This is especially salient in the Garden of Dèduit miniatures in that they show a divergence of narrative from the text. In other words, the illustrated garden setting can become a visual metaphor in its own right, as it gives way to alternative modes of interpretation.

\section{Conclusive Thoughts}

Considering the in-depth existing scholarship on the Roman de la Rose interpretations, this paper does not claim to have explored all possibilities. In this study, I chose to focus on the discrepancy between literary imageries and illustrations of the Garden of Dèduit, which suggests that the poem provided some space for the medieval reader to exert their personal interpretations. In doing so, I posit that the accompanying illustrations are key in understanding the various modes of interpretations as discussed by previous studies. The garden setting can be interpreted in various ways: whether as a reminiscent image of a long lost Eden, or as a reminder of what is at stake when immorality is concerned, or a familiar device used in other popular courtly romances. It is important to note that differences in modes of interpretation exist across manuscripts as well as within a singular manuscript. While the suggested interpretations in this study are more inclined towards Lorris's moral story, that is not to say that other illustrated scenes in the poem function similarly. For instance, while the garden illustrations suggest a religious-oriented extraneous narrative, the rest of the illustrations may revolve around other concepts such as race and military politics, as argued by Altschul (2013). Similarly, while the manuscripts examined in this study were used for religious purposes, others were most likely used outside of religious contexts. Ultimately, the study of the accompanying illustrations reinforces the non-homogenous interpretations of the 
poem. Just as good literature today provides a space for its audience to execute their sense of agency, the Roman de la Rose does nothing less.

\section{REFERENCES}

Altschul, N. (2013). Saracens and Race in Roman de la Rose Iconography: The Case of Dangier in MS Douce 195. Digital Philology, A Journal of Medieval Cultures, 2 (1), 1-15.

Arden, H. (1987). The romance of the Rose. Boston, MA: Twayne Publishers.

Delumeau, J. (2000) History of Paradise: The Garden of Eden in Myth and Tradition (Matthew O'Connell, Trans.). Chicago, IL: University of Illinois. (Original work published 1995)

Hult, D. F. (1986). Self-fulfilling prophecies: Readership and authority in the first Roman de la Rose. Cambridge University Press.

Huot, S. (1990). Medieval Readers of the Roman de la Rose: the Evidence of Marginal Notations. Romance Philology, 43(3), 400-420.

Huot, S. (1993). The Romance of the Rose and its Medieval Readers. Cambridge, MA: Cambridge University Press.

Kelly, D. (1992). The Art Medieval French Romance. Madison, WI: University of Wisconsin Press.

Lewis, S. (1992). Images of opening, penetration and closure in the Roman de la Rose. Word \& Image: A Journal of Verbal/Visual Enquiry, 8(3), 215-242.

Lorris, G., \& Meun, J. (1975). The Romance of the Rose. (F. S. Ellis, Trans). London, UK: J. M. Dent \& Sons. (Original work published in c.1270)

Luria, M., A. (1982). Reader's Guide to the Roman de la Rose. Hamden, CT: The Shoe String Press.

Milan, P. (1969). The Golden Age and the Political Theory of Jean de Meun: A Myth in Rose Scholarship. Symposium: A Quarterly Journal in Modern Literatures, 23(2), 137-149.

Porter, P. (2003). Courtly Love in Medieval Manuscripts. Toronto, Canada: University of Toronto Press.

Sturges, R. (1991). Medieval Interpretation: Models of Reading in Literary Narrative, 1100-1500. Carbondale, IL: Southern Illinois University Press.

Turner, A. (1993). The History of Hell. San Diego, CA: Harcourt Brace \& Company.

Warren, F. (1916). A Byzantine Source for Guillaume De Lorris's Roman de la Rose. Publications of the Modern Language Association of America, 31(2), 232-246. 
VI. APPENDIX

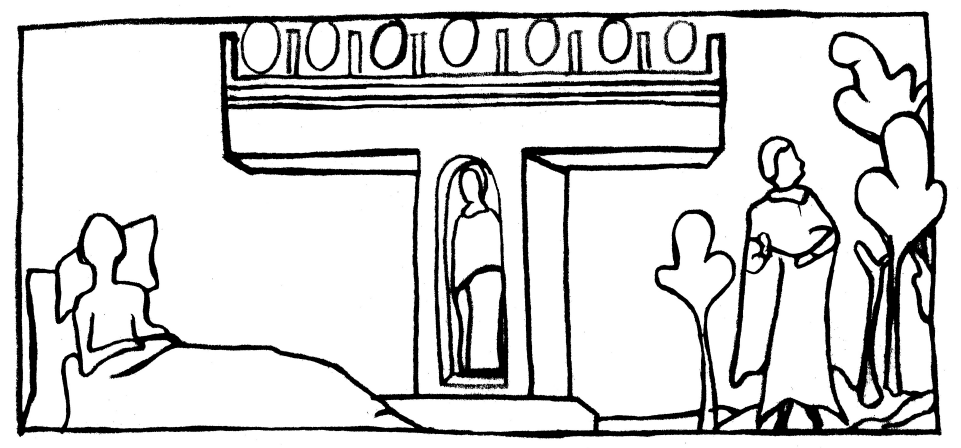

Figure 1: Discovery of Garden',f.1r, Ms. Bib. Fr. Chalons-en-Champagne 270, 14th Century, Paired with 2 texts, 29 illustrations (Ridzuan, 2016)

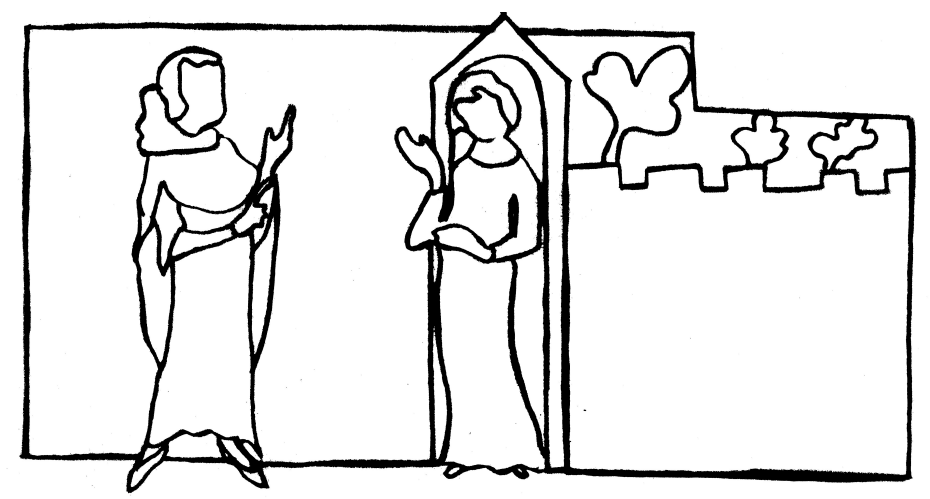

Figure 2: Idleness invites the Lover in', f.5v, Ms. Bib. Fr. Chalons-en-Champagne 270, 14th Century, Paired with 2 texts, 29 illustrations (Ridzuan, 2016) 


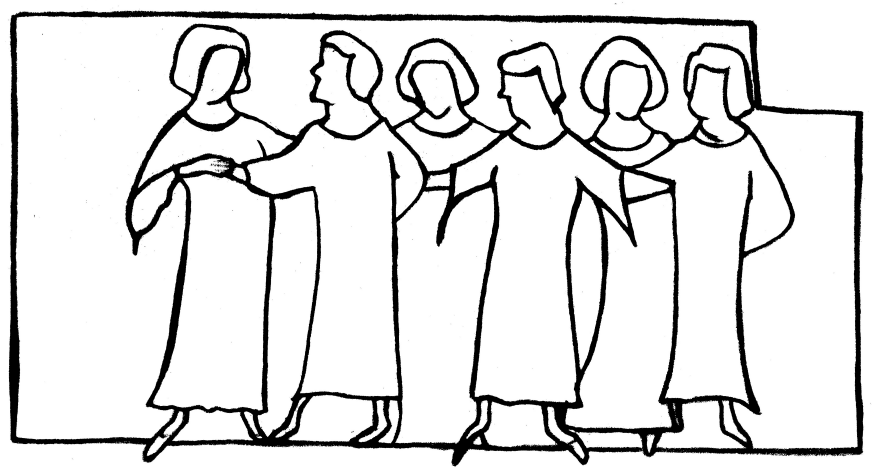

Figure 3: Dance in the garden', f.6v, Ms. Bib. Fr. Chalons-en-Champagne 270, 14th Century, Paired with 2 texts, 29 illustrations (Ridzuan, 2016)

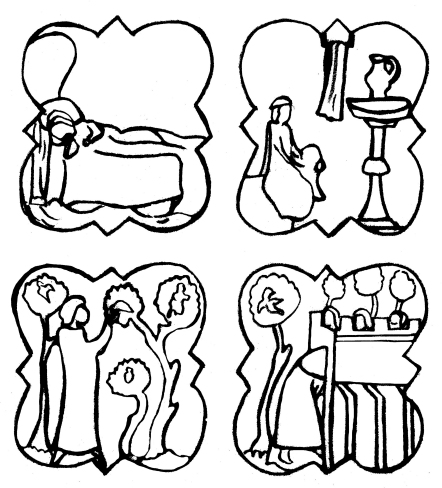

Figure 4: Dream of the garden and entry into the garden', f.2r Ms. Bib. Fr. 23488, 14th Century, Paired with 1 text, 44 illustrations (Ridzuan,2 016)

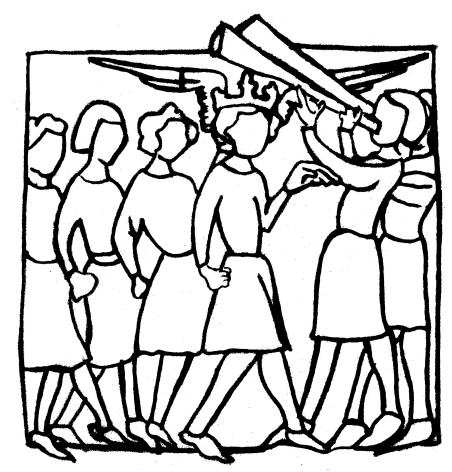

Figure 5: Dance in the garden', f.8r, Ms. Bib. Fr. 23488, 14th Century, Paired with 1 text, 44 illustrations (Ridzuan, 2016) 


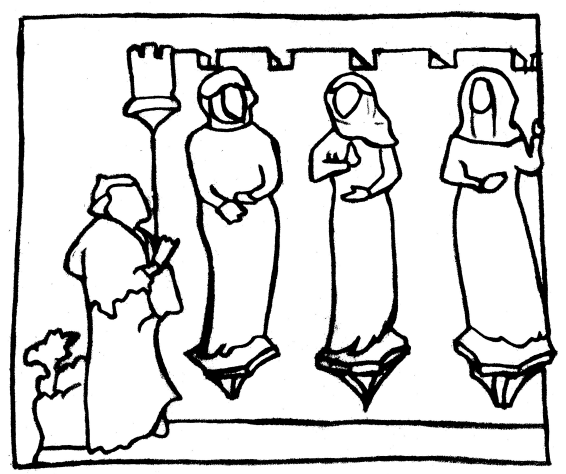

Figure 6: Discovery of the garden', f.2r, Ms. Bib. d'Arras 897, 14th Century, Paired with 11 texts, 45 illustrations (Ridzuan, 2016)

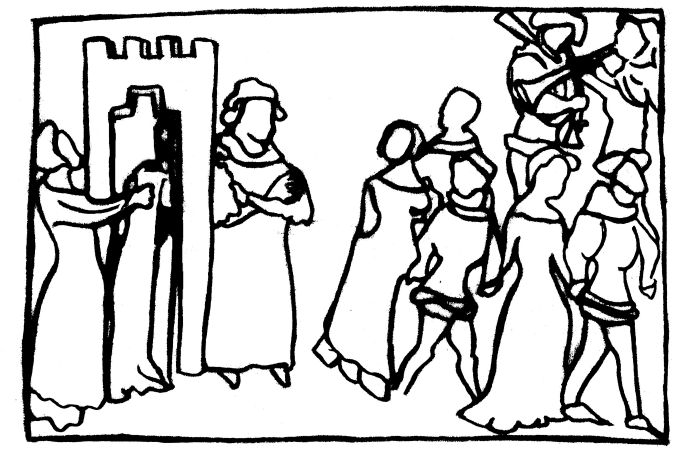

Figure 7: Entry into the garden', f.5r, Ms. Bib. d'Arras 897, 14th Century, Paired with 11 texts, 45 illustrations (Ridzuan, 2016)

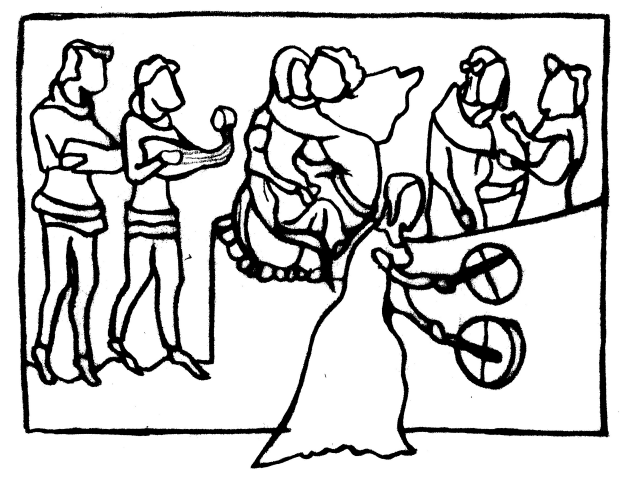

Figure 8: Dance in the garden', f.5v, Ms. Bib. d'Arras 897, 14th Century, Paired with 11 texts, 45 illustrations (Ridzuan, 2016) 

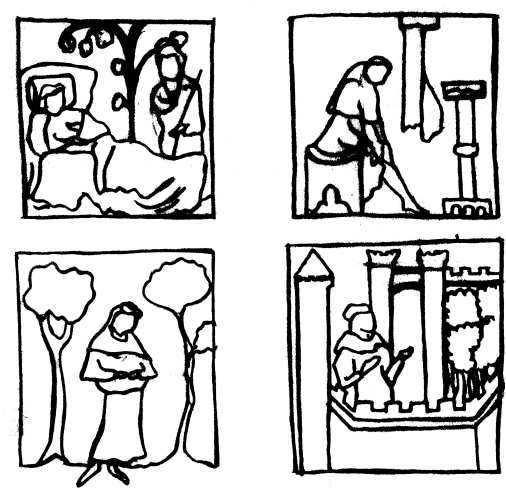

Figure 9: Dream of the garden', f.1r, Ms. Bod. Lib. Selden Supra 57, 14th Century, Paired with 1 text, 53 illustrations (Ridzuan, 2016)

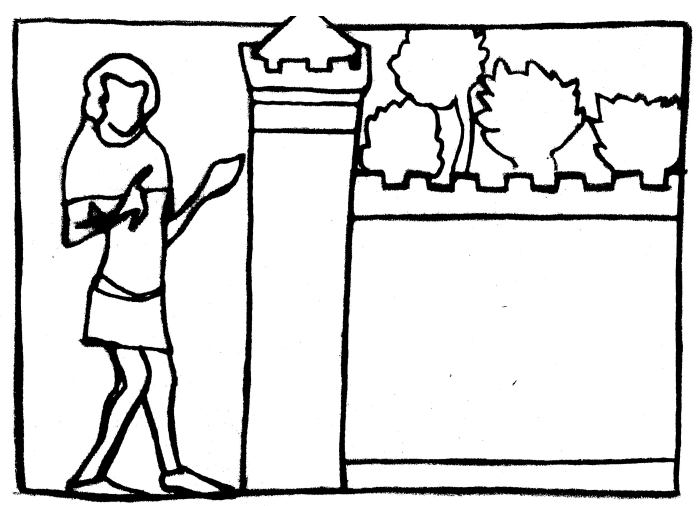

Figure 10: Discovery of the garden', f.4v, Ms. Bod. Lib. Selden Supra 57, 14th Century, Paired with 1 text, 53 illustrations (Ridzuan, 2016)

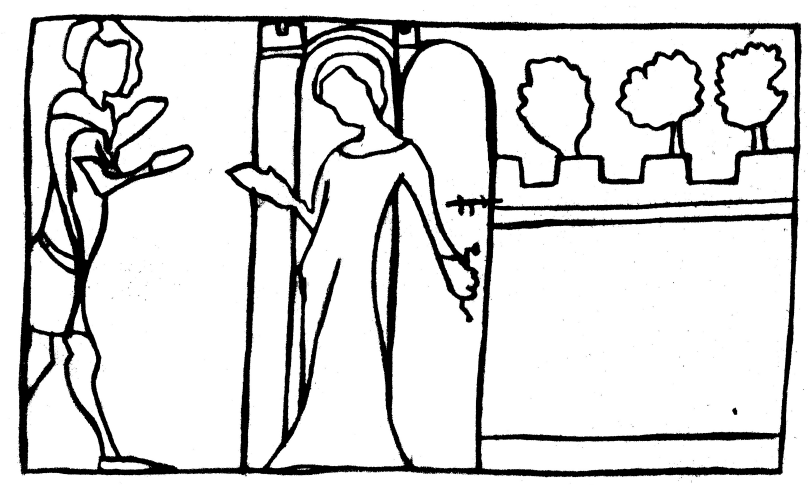

Figure 11: Idlness invites the Lover in', f.5r, Ms. Bod. Lib. Selden Supra 57, 14th Century, Paired with 1 text, 53 illustrations (Ridzuan, 2016) 


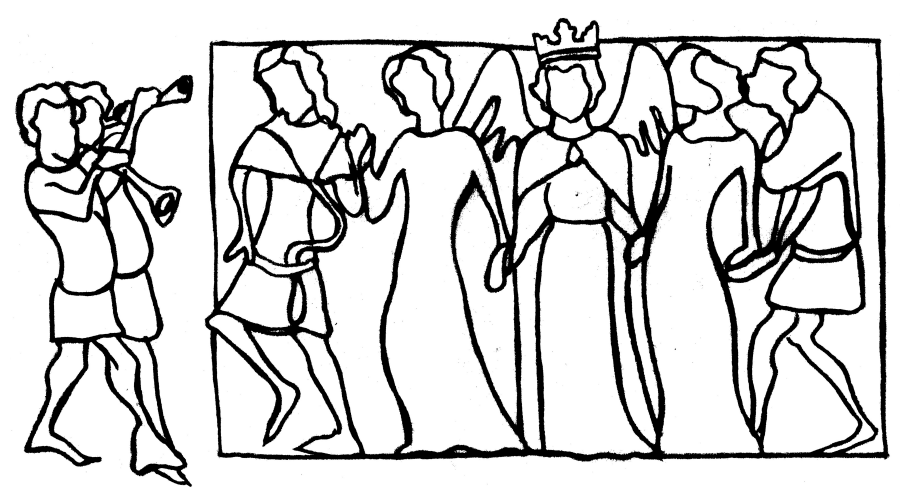

Figure 12: Dance in the garden', f.7r, Ms. Bod. Lib. Selden Supra 57, 14th Century, Paired with 1 text, 53 illustrations (Ridzuan, 2016) 